\title{
Gastrointestinal stromal tumor leading to acute abdomen and hypovolemic shock in a trauma patient
}

\author{
다 Aylin Hande Gökçe, M.D.
}

Department of General Surgery, İstanbul Medicine Hospital, İstanbul-Turkey

\begin{abstract}
Gastrointestinal stromal tumors (GISTs) are among the rare tumors of gastrointestinal (GI) tract. GISTs occur respectively in the stomach, small intestines, colon and rectum, omentum and mesentery, esophagus, retroperitoneal space, and abdominal cavity. However, they may occur anywhere along the GI tract. Typically, these tumors generally do not cause symptoms; however symptomatic patients may show stomach pain, GI bleeding, and palpable abdominal masses. These patients usually undergo surgery for obstruction symptoms or some other diagnosis. Our patient was admitted to the emergency department with acute abdomen and hypovolemic shock due to fall. The patient underwent emergency surgery, which revealed active bleeding from a stomach tumor showing an exophytic pattern of growth. This patient was a 32-year-old male, and blood tests revealed a white blood cell count of $23.500 / \mathrm{mm}^{3}$ and a hemoglobin level of $7.9 \mathrm{gr} / \mathrm{dL}$. The heart rate was 110 beats/minute. The chest radiograph showed no subdiaphragmatic free air, and abdominal ultrasound showed impression of a mass that could not be distinguished from the liver, along with closed perforation or hemangioma. During the surgical procedure, $1200 \mathrm{cc}$ of blood was suctioned, and the exophytic tumor was removed completely. Histological analysis of the tumor showed GIST, and it was considered to be a ruptured tumor by the oncology consultant. The patient was applied imatinib for 3 years after the surgery, and the disease did not re-occur during this period. Our goal in this case study is to emphasize that trauma may not be necessarily the cause of acute abdomen for emergency patients but that it also may be caused by hypotension-associated hypovolemic shock or other causes, bleeding from a GIST along with tumor torsion.
\end{abstract}

Keywords: Acute abdomen; gastrointestinal stromal tumor; hypovolemic shock.

\section{INTRODUCTION}

Gastrointestinal stromal tumors (GISTs) are among the rare tumors of gastrointestinal (GI) tract. ${ }^{[1]}$ GISTs occur respectively in the stomach, small intestines, colon and rectum, omentum and mesentery, esophagus, retroperitoneal space, and abdominal cavity. However, they may occur anywhere along the GI tract. ${ }^{[2,3]}$ Typically, these tumors do not cause symptoms; however symptomatic patients may show stomach pain, Gl bleeding, and palpable abdominal masses. ${ }^{[4,5]}$ These patients usually undergo surgery for obstruction symptoms or some other diagnosis.

Our patient was admitted to the emergency department with acute abdomen and hypovolemic shock due to fall. Here, we will be presenting the case in which the patient underwent acute GIST surgery.

\section{CASE REPORT}

A 32-year-old male patient was seen in the emergency room after a fall. A physical examination of the patient revealed a blood pressure of $80 / 40 \mathrm{mmHg}$ and a heart rate of 110 beats/minute, diffuse abdominal tenderness upon palpation, and rebound tenderness. Blood tests at the emergency laboratory revealed a white blood cell count of $23.500 / \mathrm{mm}^{3}$, a hemoglobin level of $7.9 \mathrm{gr} / \mathrm{dL}$, and a hematocrit value of $22.8 \%$. The chest radiograph did not show subdiaphragmatic free air, and abdominal radiograph in standing position was unremarkable.

Cite this article as: Gökçe AH. Gastrointestinal stromal tumor leading to acute abdomen and hypovolemic shock in a trauma patient. Ulus Travma Acil Cerrahi Derg 2019;25:83-85.

Address for correspondence: Aylin Hande Gökçe, M.D.

İstanbul Medicine Hastanesi, Genel Cerrahi Kiliniği, İstanbul, Turkey.

Tel: +90 212 - 4890800 E-mail: ahgokce79@hotmail.com

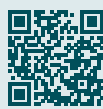

Ulus Travma Acil Cerrahi Derg 2019;25(I):83-85 DOI: 10.5505/tjtes.2018.35005 Submitted: 07.05.2018 Accepted: 03.09.2018 Online: 05.09.2018

Copyright 2019 Turkish Association of Trauma and Emergency Surgery 
Emergency ultrasound showed a $72 \mathrm{~mm}$ epigastric lesion, undistinguishable from the left lobe of the liver and surrounded with fluid. Based on ultrasound findings suggesting a hemangioma or closed perforation, the patient was diagnosed with intra-abdominal bleeding and acute abdomen, and he underwent emergency surgery. A mass arising from the body of the stomach was detected during the surgery. The mass was $9 \times 7 \times 6 \mathrm{~cm}$ in size and showed an exophytic growth pattern (Fig. Ia, b). Approximately $1200 \mathrm{cc}$ of blood was suctioned from the abdominal cavity. The tumor was totally removed along with the part of the stomach where the tumor was connected with the body of the stomach. The body of the stomach was repaired as double layers. Other intra-abdominal organs were intact. During the post-operative period, the patient was stable and did not develop any complications until he was discharged from the hospital.

A low-grade GIST was reported based on the histological findings. Mitotic count was less than 5 per 50 high-power fields. The tumor was positive for CD 117 (c-kit) and DOG-I and focally positive for CD 34, while it was negative for S- 10 and SMA. Ki-67 proliferation index was less than $5 \%$. Histologic examination revealed torsion-related hemorrhagic necrosis and edema, which might explain large dimensions of the tumor. The tumor stage was reported as PT3.

The patient was referred to the Department of Oncology after the surgery. The tumor was accepted as ruptured in the Department of Oncology, and the patient received imatinib therapy for 3 years. The disease did not recur during this period of time.

\section{DISCUSSION}

GISTs are mesenchymal tumors arising from interstitial cells, and they may occur in the gastrointestinal canal anywhere from esophagus to anus along with omentum, mesentery, and retroperitoneal space. ${ }^{[6]}$ GISTs usually occur after the fourth decade of life, and the mean age of occurrence is approximately $60 \mathrm{~s} .{ }^{[7]}$ The patient presented in this paper was 32 year old, and considering the age range reported in the literature, he was relatively younger. GISTs are usually asymptomatic or may cause non-specific symptoms such as abdominal pain, anemia, abdominal masses, and dyspepsia. These tumors are usually detected incidentally during a surgical, radiological, or endoscopic procedure that is done for any other reasons. ${ }^{\left[{ }^{8,9]}\right.}$ With the patient presented here, GIST bleeding into the abdominal cavity led to symptoms of hypovolemic shock, and tumor torsion led to acute abdomen. The patient was not hematologically stable, and he needed an emergency laparotomy. Pre-operative differential diagnosis of gastrointestinal stromal tumors may present challenges. Based on an emergency ultrasound scan, preliminary diagnoses in this patient include bleeding hemangioma and closed perforation.

Prognostic factors in GIST are mitotic activity, size, location of the tumor, and the feasibility of performing optimum surgery. [10] GISTs are divided into risk groups based on tumor size: tumors less than $2 \mathrm{~cm}$ in diameter are classified as the low-risk group, and tumors larger than $5 \mathrm{~cm}$ in diameter are classified as the high-risk group. Higher $\mathrm{Ki}-67$ proliferation index values further increase the risk for metastasis and recurrences. In the case of GIST presented here, the $\mathrm{Ki}-67$ proliferation index value was less than $5 \%$, although the tumor was $9 \times 7 \times 6$ $\mathrm{cm}$ in size. Even though the tumor was larger than $2 \mathrm{~cm}$ in diameter, it was considered a low-grade tumor by pathologists. Torsion-related hemorrhagic necrosis and edema were the reported underlying causes of the increase in tumor size. It was concluded that hypovolemic shock was the result of bleeding from the stomach tumor with exophytic extension and subsequently tumor-torsion-caused symptoms of acute abdomen.
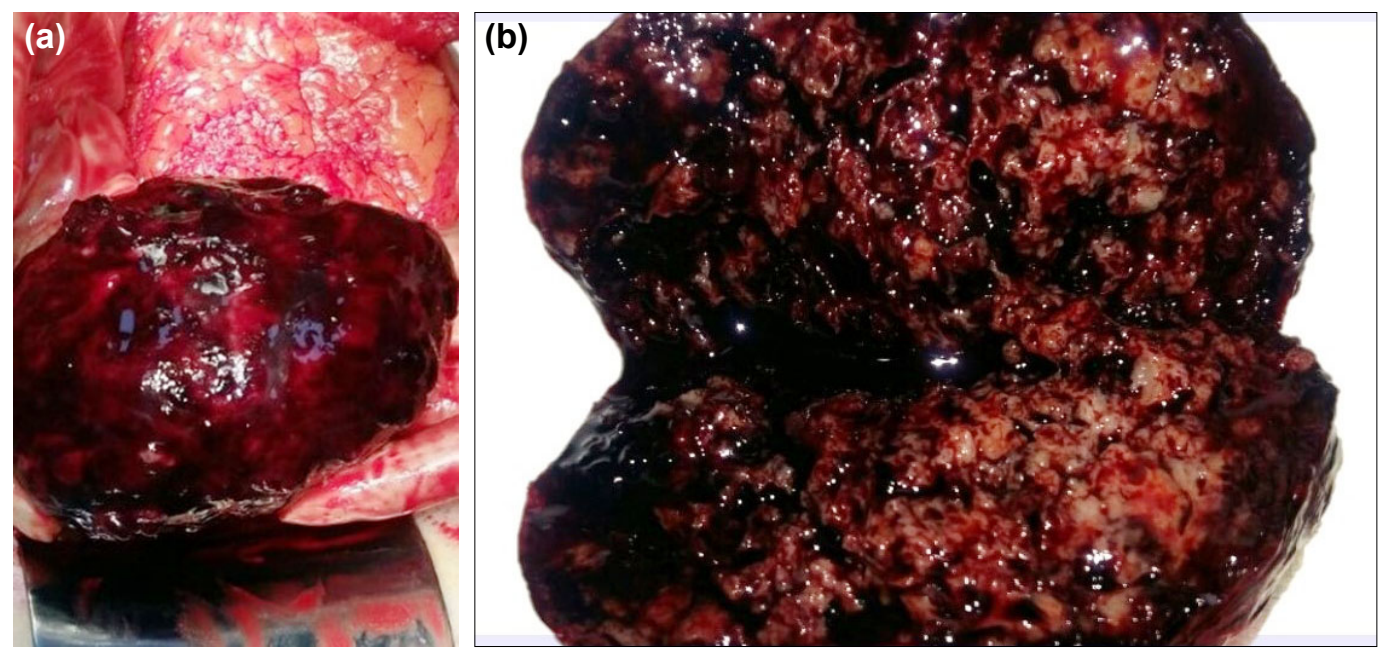

Figure 1. (a) Gastrointestinal stromal tumors showing an exophytic pattern of growth, from the corpus of stomach. (b) A piece of the gastrointestinal stromal tumors. 
A carefully obtained medical history and a meticulous physical examination are of paramount importance in trauma patients admitted to emergency services. We believe that trauma patients are best managed by adequate pre-operative preparations to the extent of hematological stability and optimum surgery. Post-operative diagnosis may differ from pre-operative diagnosis in some of the emergency patients as with our patient. In such cases, a rapid planning of the management is essential to perform the optimum goal-oriented surgery. In addition, next to common causes of acute abdomen, there are also rare causes of acute abdomen as with our patient, and one should be prepared for such circumstances.

\section{Conclusion}

In this case report, we aimed to emphasize the findings of acute abdomen exposure to the torsion of GISTs and bleeding shock. Trauma may not be necessarily the cause of acute abdomen for an emergency patient, but it may also be caused by hypotension-associated hypovolemic shock or other causes, bleeding from a GIST, along with tumor torsion.

Conflict of interest: None declared.

\section{REFERENCES}

1. Kim CJ, Day S, Yeh KA. Gastrointestinal stromal tumors: analysis of clinical and pathologic factors. Am Surg 2001;67:135-7.

2. Gold JS, Dematteo RP. Combined surgical and molecular therapy: the gastrointestinal stromal tumor model. Ann Surg 2006;244:176-84.

3. Engin G, Asoglu O, Kapran Y, Mert G. A gastrointestinal stromal tumor with mesenteric and retroperitoneal invasion. World J Surg Oncol 2007;5:121. [CrossRef]

4. Pidhorecky I, Cheney RT, Kraybill WG, Gibbs JF. Gastrointestinal stromal tumors: current diagnosis, biologic behavior, and management. Ann Surg Oncol 2000;7:705-12. [CrossRef]

5. Lehnert T. Gastrointestinal sarcoma (GIST)-a review of surgical management. Ann Chir Gynaecol 1998;87:297-305.

6. Duffaud F, Blay JY. Gastrointestinal stromal tumors: biology and treatment. Oncology 2003;65:187-97. [CrossRef]

7. Sturgeon C, Chejfec G, Espat NJ. Gastrointestinal stromal tumors: a spectrum of disease. Surg Oncol 2003;12:21-6. [CrossRef]

8. Pierie JP, Choudry U, Muzikansky A, Yeap BY, Souba WW, Ott MJ. The effect of surgery and grade on outcome of gastrointestinal stromal tumors. Arch Surg 2001;136:383-9. [CrossRef]

9. Levine MS, Buck JL, Pantongrag-Brown L, Buetow PC, Hallman JR, Sobin LH. Leiomyosarcoma of the esophagus: radiographic findings in 10 patients. AJR Am J Roentgenol 1996;167:27-32. [CrossRef]

10. Dougherty MJ, Compton C, Talbert M, Wood WC. Sarcomas of the gastrointestinal tract. Separation into favorable and unfavorable prognostic groups by mitotic count. Ann Surg 1991;214:569-74. [CrossRef]

\section{OLGU SUNUMU - ÖZET}

\section{Travmalı hastada akut batın ve hipovolemik şok yapan gastrointestinal stromal tümör}

\section{Dr. Aylin Hande Gökçe}

İstanbul Medicine Hastanesi, Genel Cerrahi Kliniği, İstanbul

Gastrointestinal stromal tümör (GIST), gastrointestinal sistemin nadir görülen tümörlerinden biridir. Gastrointestinal sistemin her yerinde olabilir ama en sık sırasıyla görüldüğü yerler mide, ince bağırsaklar, kolorektal, omentum/mezenter, özefagus ve nadiren gastrointestinal sistem ile bağlantısız olarak retroperiton veya abdomendir. Genelde semptomsuz seyreder. Semptomlu olursa karın ağrısı, gastrointestinal sistem kanaması, elle muayenede ele gelen kitle gibi bulgular verebilir. Hastalar genellikle obstrüksiyon bulguları ve başka tanılarla ameliyata alınmaktadır. Sunacağımız olgu acil kliniğe düşme sonrası akut karın ve hipovolemik şok bulgularıyla getirilen, acil şartlarda operasyona alınan ve operasyonda mideden kaynaklı eksofitik büyümüş tümör kanaması olduğu saptanan olgudur. Olgu 32 yaşında, erkek hasta ve yapılan kan incelemelerinde lökosit sayımı 23.500/ $\mathrm{mm}^{3}$, hemoglobin değeri $7.9 \mathrm{gr} / \mathrm{dL}$, nabız I I0/dk idi. Akciğer grafisinde diafragma altı serbest hava saptanmayan, ultrasonografisinde karaciğerden ayırt edilemeyen kitlesel görünüm arzeden ve kapalı perforasyon - hemanjiom ayrımı yapılamayan hasta ameliyata alındı. Ameliyatta yaklaşık I 200 cc kan aspire edildi ve mideden ekzofitik uzanım gösteren kitle total olarak çıkarıldı. Patoloji sonucu GiST olarak gelen hasta onkoloji bölümü tarafından rüptüre kabul edildi. Ameliyat sonrası üç yıl imatinib tedavisi verildi ve bu süre içinde nüks saptanmadı. Travma sonucu acile başvuran hastalarda akut karın nedeninin her zaman travmayla ilgili olmayabileceği, hipovolemik şok veya başka nedenlerden dolayı tansiyon düşmesi sonucu travmanın gerçekleşebileceğini vurgulamak ve GiST'nin kanayıp hipovolemik şoka ve torsiyona uğrayıp akut batın bulgularına yol açabileceğini sunmak istedik. Anahtar sözcükler: Akut karın; gastrointestinal stromal tümör; hipovolemik şok. 